Check for updates

Cite this: Mater. Adv., 2020 1,1494

Received 19th May 2020,

Accepted 14th August 2020

DOI: $10.1039 / \mathrm{d} 0 \mathrm{ma} 00329 \mathrm{~h}$

rsc.li/materials-advances

\section{Cold atmospheric plasma cancer treatment, direct versus indirect approaches}

\author{
Alisa Malyavko, $\dagger^{\mathrm{a}}$ Dayun Yan, $\dagger^{\star^{\mathrm{b}}}$ Qihui Wang, ${ }^{\mathrm{b}}$ Andrea L. Klein, ${ }^{\mathrm{a}}$ Khyati C. Patel, ${ }^{\mathrm{c}}$ \\ Jonathan $\mathrm{H}$. Sherman ${ }^{d}$ and Michael Keidar (D) *b
}

\begin{abstract}
Cold atmospheric plasma (CAP), an ionized gas with near room temperature, shows a wide application in medicine. CAP is a tunable source of complex chemical components including many reactive species, which allows CAP to exert many biological effects on bacterial, fungal, yeast, and mammalian cells particularly cancer cells. In this review, we discuss the novel state of the art CAP-based cancer treatment. We focus on the comparison between the direct CAP treatment and the indirect CAP treatment which implements the use of CAP-activated solutions. The difference between the two treatment strategies reveals two unique features of the biological response to CAP: the cell-based $\mathrm{H}_{2} \mathrm{O}_{2}$ generation and the activation phenomenon. Short-lived reactive species and physical factors from plasma may trigger these two cellular responses.
\end{abstract}

\section{Background}

The state of plasma is generally defined as an ionized gas composed of positively charged ions, electrons, and neutral particles. $^{1,2}$ The ionization of gas can be achieved by the particle collision with the energies higher than their energy thresholds. Heating and applying an electric field are two common ionization pathways. Generally, the temperature of matter increases when the matter transitions from a gas to a plasma. The temperature of the plasma is determined by the thermal motions of heavy particles such as ions and neutral particles. Due to the intensive elastic collisions between electrons and heavy particles in the ionized gas, all particles reach thermal equilibrium and form a thermal plasma, such as arc and radio-frequency inductively coupled plasma. ${ }^{3,4}$ In this case, the discharge is associated with Joule heating and thermal ionization and enables the delivery of high power. ${ }^{4}$ Thermal equilibrium plasma is measured to have a high temperature, over a thousand degrees.

When the discharge is carried out under a fast but relatively low energy input, a plasma in thermal non-equilibrium can be achieved. ${ }^{5,6}$ Plasma in thermal non-equilibrium has weak elastic

\footnotetext{
${ }^{a}$ School of Medicine and Health Science, George Washington University, Washington, District of Columbia, 20052, USA

${ }^{b}$ Department of Mechanical and Aerospace Engineering, George Washington University, Washington, District of Columbia, 20052, USA.

E-mail: ydy2012@gwmail.gwu.edu, keidar@gwu.edu

${ }^{c}$ Department of Biomedical Engineering, George Washington University,

Washington, District of Columbia, 20052, USA

${ }^{d}$ WVU Medicine - Berkeley Medical Center, West Virginia University, Martinsburg, West Virginia, 25401, USA

$\dagger$ Authors contributed equally to this work.
}

collisions between electrons and heavy particles, therefore, the temperature of heavy particles will be approximately near room temperature. ${ }^{6}$ Such a plasma is referred to as a nonthermal plasma. When such discharge process occurs under the atmospheric conditions, it is referenced to as cold atmospheric plasma (CAP). CAP has plenty of reactive chemical components generated in the complex ionization process, producing short-/long-lived reactive oxygen species (ROS) and reactive nitrogen species (RNS). ${ }^{7,8}$ These features allow CAP to be widely used in biomedicine. A myriad of key cellular responses can be affected by reactive species or other physical factors from CAP. Therefore, the concept of CAP-based cancer treatment has shown a rapid growth of interest over the past decade (Fig. 1). ${ }^{9-14}$

Many different CAP sources exist, however, they can roughly be divided into two categories, the indirect discharge sources and the direct discharge sources. ${ }^{15}$ To avoid the arc discharge, either the anode or cathode is covered by a layer of dielectric materials such as quartz in practice. ${ }^{16}$ In many designs, a quartz hollow tube is used as the dielectric layer on the annulus cathode ${ }^{13,17}$ For an indirect discharge CAP source, the discharge is triggered in noble gases such as helium (He) and argon (Ar) under a relatively low energy input. $\mathrm{He}$ and Ar facilitate the stable generation of glow-like discharges at a low gas temperature and low energy input. ${ }^{4}$ The ionized gas is further transported from the main discharge area to the environment by the noble gas. ${ }^{18}$ The nitrogen $\left(\mathrm{N}_{2}\right)$ and oxygen $\left(\mathrm{O}_{2}\right)$ in the air, or from a specific supply, can also be used in the non-equilibrium discharge and finally form a stable bulk plasma as a jet shape gas with a high aspect ratio. $\mathrm{N}_{2}$ and $\mathrm{O}_{2}$ can also modulate the chemical components in CAP. ${ }^{19}$ The CAP jet source is also known as a plasma pencil, plasma needle, or plasma gun in some ref. 12. The CAP jet can penetrate narrow 




Fig. 1 The publication number versus year. Only the papers and reviews focused on cancer treatment have been listed. The photos are three typical CAP sources, reproduced with permission from T. Von Woedtke et al., In Vivo, 2019, 33, 1011-1026.

gaps, making it particularly interesting for its application in situations involving complex geometries with cavities or capillaries. ${ }^{3}$

For the direct discharge sources, the sample is one of the electrodes involving the discharge. A typical direct discharge source used in plasma medicine is the dielectric barrier discharge (DBD). ${ }^{20}$ Plasma will not be generated in DBD if the sample is not adequately close to the second electrode covered by a dielectric layer. Such a layer limits the discharge current. ${ }^{3}$ DBD can generate a wide but short plasma, which may be more suitable for a more intense treatment on a large area sample. The effective gap to generate plasma in DBD ranges from micrometers up to centimeters depending on the discharge environment such as the gas components and the operating voltage. ${ }^{3}$ DBD can work directly in the air without the supply of noble gas, which is at the expense of higher input energy to trigger the discharge. Typical operation parameters of DBD are: ignition voltage (kilovolts), frequency (megahertz), and power consumption ( $\mathrm{W}$ per $\mathrm{dm}^{2}$ electrode area). ${ }^{3}$ Volume DBD and surface DBD are two DBD widely used in plasma medicine (Fig. 1). ${ }^{8}$

The demonstration of the anti-tumor effect in vivo is the foundation of the clinic application of CAP sources. So far, several CAP sources have been used to directly treat the subcutaneously xenografted tumors above the skin. ${ }^{21-27}$ It is found that the growth of a tumor could be effectively halted after the treatment in most cases, which also results in the extended length of life and higher survival rate of mice. ${ }^{28-31}$ We introduced one example at here. A nanosecond pulsed DBD (nsP DBD) could completely eradicate the melanoma tumor in mice by the direct treatment on the tumor site. ${ }^{27}$ The control tumor continued to grow up to day 19 (D19) post-injection until mice was sacrificed. Mice treated with nsP DBD continued to heal with a scab up to 22 days and after were tumor free (Fig. 2a). The survival rate of mice has also been drastically increased from $0 \%$ (control) to $66.7 \%$ 20-40 days after the treatment (Fig. 2b). Histological investigation confirmed the complete eradication of melanoma tissue after the treatment (Fig. 2c). CAP also shows a promising effect in the clinical trials involving the locally advanced head and neck cancer patients. ${ }^{32}$

\section{The anti-cancer effect in vitro}

To understand the anti-tumor mechanism demonstrated in vivo, plenty of in vitro studies have been performed over the past decade. Our discussion will focus on this topic in the following sections.
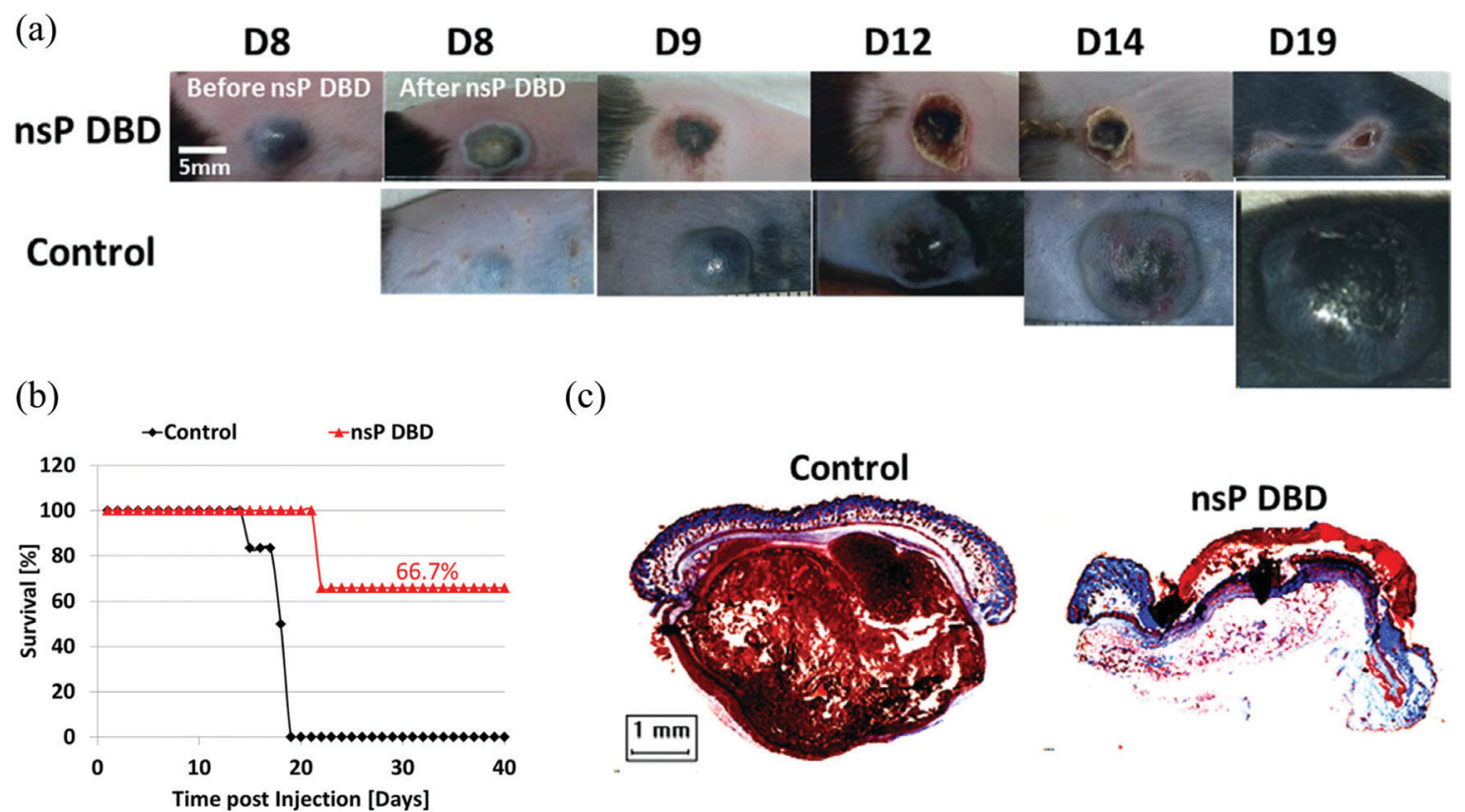

Fig. 2 The eradication of melanoma tumor in mice using a nspDBD source. (a) B16 Melanoma cells were injected on the rear flank of C57BL/6 mice. After 8 days, the tumor was treated a single time for $7 \mathrm{~min}$ with nsP DBD at $236 \mathrm{~Hz}$ and $33.6 \mathrm{kV}$. (b) Survival for nsP DBD treated tumors (red triangle) and control untreated tumors (black diamond) as a function of time post-injection. (c) The trichrome staining of nsP DBD treated tumor (left top, D22 post-injection) and control tumor (left bottom, D19 post injection). Histology of the nsP DBD treated tumor showed red skin staining confirming scab formation but no visible tumor below the epithelium. (Reproduced with permission from N. Chernets et al., Plasma Processes Polym., 2015, 12, 1400-1409). 
CAP has been demonstrated as a powerful tool to kill dozens of cancer cell lines in vitro. ${ }^{21,22}$ A wide range of cancer types can be killed by CAP including skin cancer, breast cancer, colorectal cancer, cervical cancer, lung cancer, head and neck cancer, leukemia, hepatoma, as well as very fatal cancers such as brain cancer particularly glioblastoma. ${ }^{9}$ Some chemo-resistant cell lines are also sensitive to the CAP treatment, such as temozolomide (TMZ)-resistant glioblastoma cells, the tumor necrosis factor-related apoptosis-inducing ligand (TRAIL)-resistant colorectal cancer cells, the paclitaxel-resistant, and the tamoxifen sensitivity breast cancer cells, and the 5-fluorouracil-resistant hepatocarcinoma cells. ${ }^{33-37}$ CAP also shows selective anti-cancer effect in several cancer cell lines, which enables CAP as an attractive anti-cancer tool. ${ }^{22,38-42}$ The synergistic use of CAP with other methods such as nanotechnologies, extra static magnetic field, as well as a pulsed electric field will enhance the efficacy of CAP treatment. ${ }^{43-50}$ The anti-cancer mechanism in vitro is also complicated. Based on over 400 references, some general conclusions have been made so far. The reactive species mainly ROS, affect cellular function through the overturn of the intracellular redox balance as well as the damaging the membrane anti-oxidant enzymes, causing the noticeable rise of intracellular ROS via complex pathways (Fig. 3a). ${ }^{51-54}$ Intracellular ROS cause a variety of damage to important cellular components such as the cellular membrane, DNA, mitochondria, and endoplasmic reticulum and finally trigger apoptosis, necrosis, autophagy-associated cell death, or senescence (Fig. 3b). ${ }^{55-61}$ A ROS scavenger, either extracellular or intracellular, can effectively counteract the cytotoxicity of CAP treatment on most cancer cells. ${ }^{24,41,53}$

Generally, there are two strategies to do CAP treatment in vitro (Fig. 4a). One strategy is the direct CAP treatment, which involves the treatment of cells directly. All factors of CAP will have the chance to affect the cells in some way. In practice, cancer cells are always immersed in a layer of cell culture medium or other biological adaptable solutions to simulate the culture environment. Such a medium layer facilitates the transition of the short-lived reactive species into the long-lived reactive species. ${ }^{19,62-65}$ The short-lived reactive species, as well as physical factors in CAP, may also play some roles to trigger the cytotoxicity. However, only the long-lived reactive species have been proved to be the key player in most cases. ${ }^{66-69}$ Among diverse ROS/RNS, $\mathrm{H}_{2} \mathrm{O}_{2}$ has been regarded as the main anti-cancer reactive species. ${ }^{66-69}$ However, $\mathrm{H}_{2} \mathrm{O}_{2}$ alone cannot explain all of the observable cytotoxicity. ${ }^{52,62,70-76} \mathrm{NO}_{2}{ }^{-}, \mathrm{NO}_{3}{ }^{-}$, and $\mathrm{ONOO}^{-}$may also contribute to the cytotoxicity. ${ }^{77-79}$

Besides, the aqueous solutions to carry these reactive species also play a key role to determine the cytotoxicity of CAP treatment. On one hand, the chemistry of reactive species in the gaseous phase becomes more complex when they interact with water (Fig. 4b). It will not be the same when we consider the chemical components in the CAP treated deionized water, buffered solutions, and cell culture media. On the other hand, the cells will have different cellular responses to the same reactive species in different solutions, such as in phosphate-buffered saline (PBS) and in DMEM. There will be no anti-cancer effect when the CAP treatment is performed on the cells immersed in PBS. ${ }^{75,76,80}$
The same treatment in DMEM will cause a much stronger effect. These differences may be due to the different cellular responses and biochemical pathways to the nutrient-rich and the nutrientpoor environments. In short, the previous studies will simplify the CAP-based anti-cancer mechanism if the long-lived reactive species has been proposed to be the only anti-cancer factor.

In addition to the direct CAP treatment, the strategy of indirect CAP treatment also shows strong anti-cancer capacity. The indirect treatment in vitro is performed by affecting the growth of cancer cells using the CAP-treated (activated) solutions (PAS). ${ }^{81,82}$ PAS is generally achieved by using DBD sources or CAP jet sources to treat the biological adaptable solutions such as medium, PBS, or other solutions like Ringer's solution. ${ }^{83}$ PAS can also be created by the discharge in medium. ${ }^{84}$ Such strategy is fully based on the long-lived reactive species and the products formed in the reaction between bulk CAP and the original components in solutions such as the amino acids in medium and the lactate in Ringer's solution. ${ }^{81,85-92}$ PAS can be safely stored under certain conditions for a long time. ${ }^{72,73,93}$ This feature may be a key unique aspect of the indirect treatment, which allows CAP to be used as a pharmacological method.

\section{Direct treatment $v s$. indirect treatment}

If the anti-cancer capacity is mainly due to the long-lived reactive species, it could be assumed that direct CAP treatment affects the growth and viability of cancer cells in the same way as indirect CAP treatment does. However, the experimental data show that the direct CAP treatment tends to cause stronger cytotoxicity than the indirect CAP treatment, even though the concentration of $\mathrm{H}_{2} \mathrm{O}_{2}, \mathrm{NO}_{2}{ }^{-}, \mathrm{NO}_{3}{ }^{-}$in the extracellular environment is the same in both cases (Fig. 5a and b). ${ }^{75,94}$ Thus, the CAP treatment in vitro cannot simply be expressed as the treatment by a specific long-lived reactive species, such as $\mathrm{H}_{2} \mathrm{O}_{2}$ - treatment, $\mathrm{NO}_{2}{ }^{-}$- treatment, $\mathrm{NO}_{3}{ }^{-}$- treatment, or $\mathrm{ONOO}^{-}$- treatment.

For the direct treatment, at least three CAP-related factors may impact cancer cells: the short-lived reactive species, the longlived reactive species, and the physical factors. In the indirect CAP treatment, only the long-lived reactive species, need to be considered. Therefore, either short-lived reactive species or physical factors should be responsible for the stronger anticancer capacity of the direct CAP treatment. For the direct treatment, when the extracellular medium containing reactive species is immediately removed $(<30 \mathrm{~s})$ following the treatment, the cytotoxicity is almost counteracted. ${ }^{95}$ Therefore, the CAPoriginated long-lived reactive species are necessary for the anticancer effect. The CAP-originated short-lived reactive species and/ or physical factors may amplify such cytotoxicity of long-lived reactive species or may trigger the generation of long-lived reactive species from cells.

In the following sections, we will focus on two unique cellular responses to the direct CAP treatment: the cell-based $\mathrm{H}_{2} \mathrm{O}_{2}$ generation and the activation phenomenon. These two cellular responses can be regarded as two basic features to discriminate the direct CAP treatment from the indirect CAP treatment. The conventional studies mainly focused on the long-term cellular 
(a)

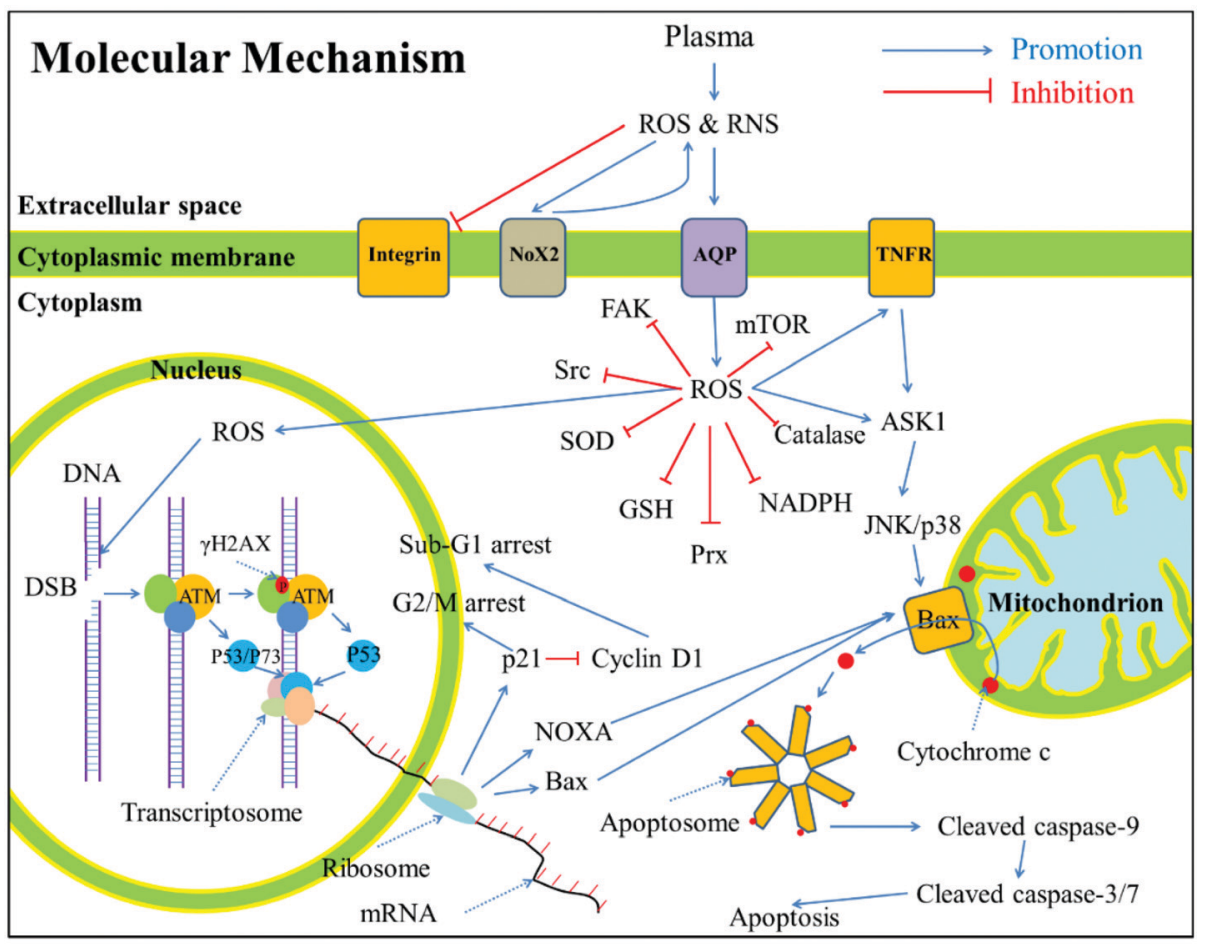

(b)

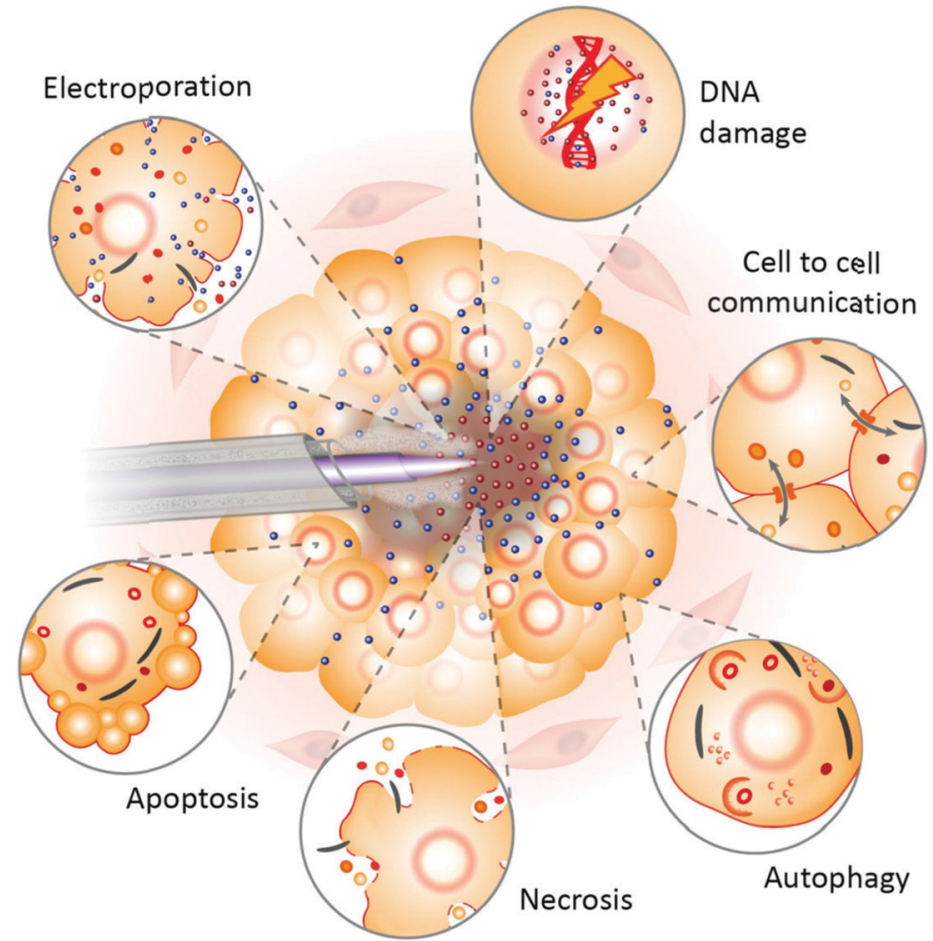

Fig. 3 The anti-cancer mechanism in vitro. (a) A general summary for the anti-cancer mechanism of CAP (Reproduced with permission from D. Yan et al., Oncotarget, 2017, 8(9), 15977). (b) A schematic description of the biological impact of CAP on cancer cells (Reproduced with permission from A. M. Hirst et al., Tumor Biol., 2016, 37, 7021-7031).

responses to the CAP treatment, such as apoptosis and other cellular damage. ${ }^{46,59,96-100} \mathrm{H}_{2} \mathrm{O}_{2}$ as a typical long-lived reactive species, can affect cells for several hours until they are fully consumed by cells. ${ }^{75}$ In contrast, these two cellular responses are all short-term cellular responses, triggered by the CAP treatment lasting several minutes.

\section{The cell-based $\mathrm{H}_{2} \mathrm{O}_{2}$ generation}

In plasma medicine, the cell-based $\mathrm{H}_{2} \mathrm{O}_{2}$ generation is the first experimental evidence for the short-term cellular response to CAP treatment. In nearly all previous studies, cancer cells have 
(a)

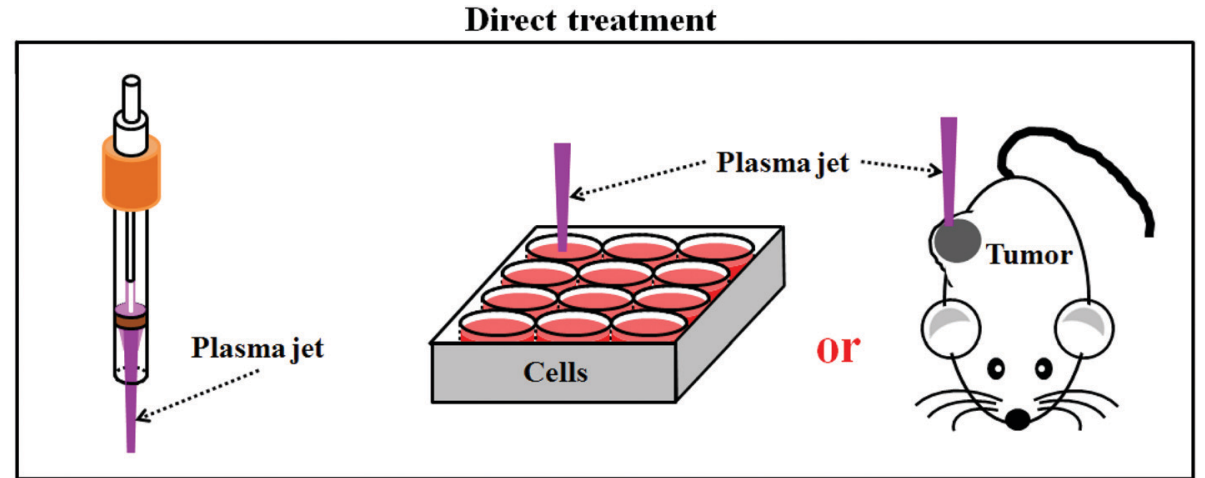

Indirect treatment

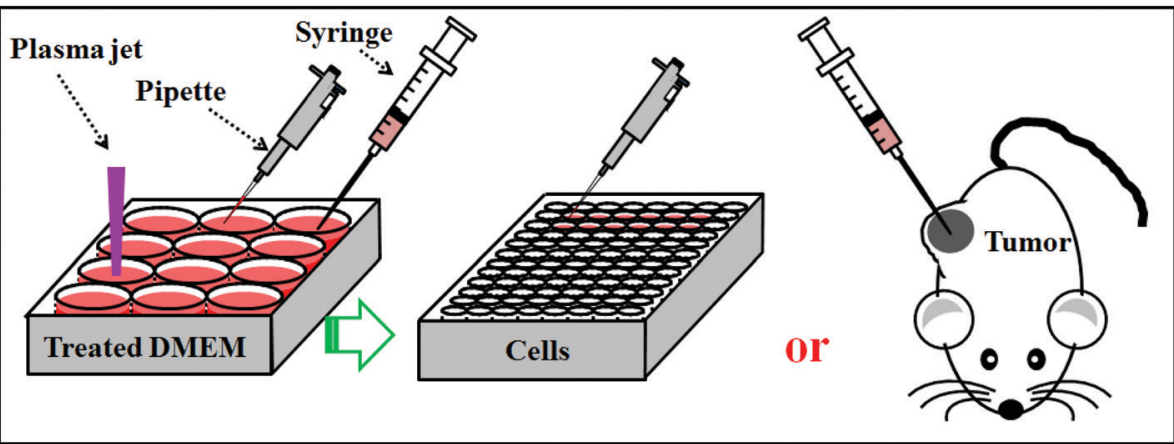

(b)



Fig. 4 Direct CAP treatment and indirect CAP treatment. We used DMEM as an example at here. (a) The schematic illustration of the two treatment strategies (Reproduced with permission from D. Yan et al., Oncotarget, 2017, 8, 15977). (b) The transition of reactive species in the direct CAP treatment on the water (Reproduced with permission from P. Sellam, et al., Comprehensive Reviews in Food Science and Food Safety, 2019, 18(6), 1985-2008).

been regarded as a passive target of the CAP-originated reactive species. ${ }^{14,101,102}$ During the treatment, for example, the longlived reactive species such as $\mathrm{H}_{2} \mathrm{O}_{2}, \mathrm{NO}_{2}{ }^{-}, \mathrm{NO}_{3}{ }^{-}$, and $\mathrm{ONOO}^{-}$ and the short-lived reactive species such as $\mathrm{O}_{2}{ }^{-}$and $\mathrm{OH}^{\bullet}$ are generated simultaneously in the medium. Their specific roles in the cytotoxicity of CAP treatment are ambiguous. The shortlived reactive species are believed to transform into the longlived reactive species and further affect cancer cells. We recently developed a method to measure the potential cell-based longlived reactive species generation. ${ }^{103}$ This is a simple method to capture such a quick response, which can be easily repeated in any plasma medicine laboratories (Fig. 6a).

The cell-based $\mathrm{H}_{2} \mathrm{O}_{2}$ generation was first observed in two cancer cell lines, a triple-negative breast cancer cell line MDAMB-231 and a pancreatic adenocarcinoma cell line PA-TU-8988T (Fig. 6b). ${ }^{103}$ Both of these cell lines generated micromolar $(\mu \mathrm{M})$ 
(a)

MDA-MB-231 cells

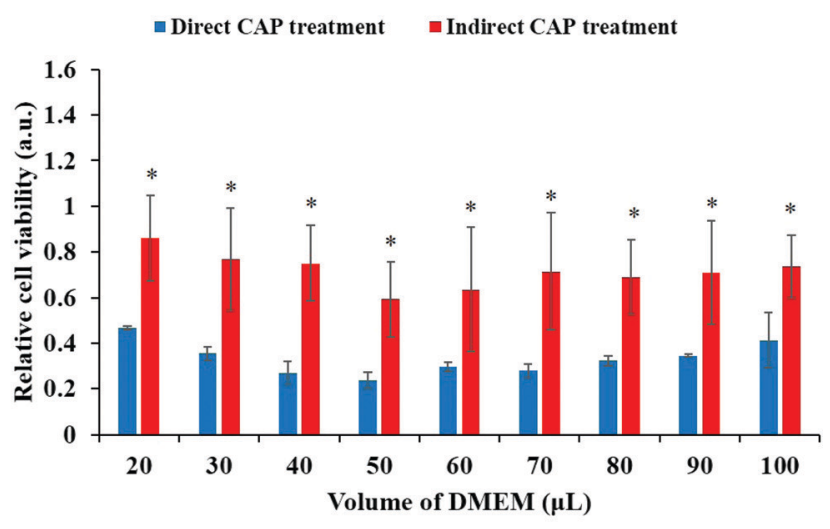

(b)

PA-TU-8988T cells

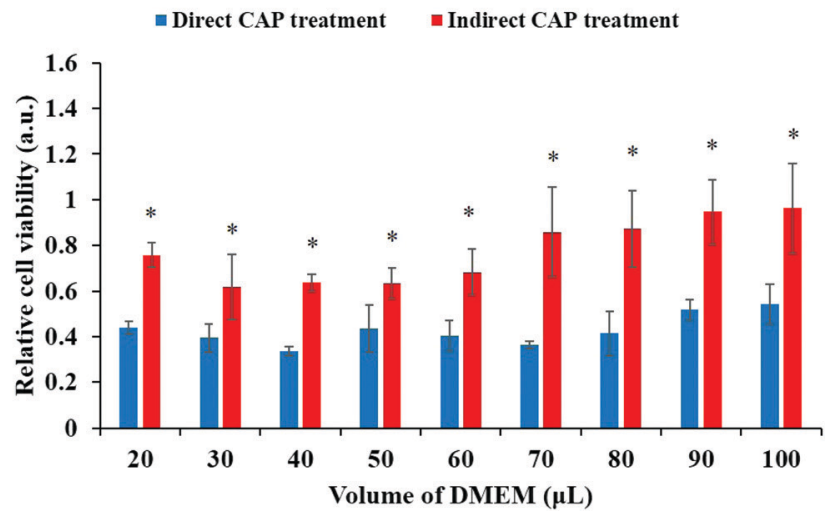

Fig. 5 The direct CAP treatment causes a stronger anti-cancer effect compared with the indirect CAP treatment based on the CAP-treated media. The comparative studies were performed on breast cancer cell line MDA-MB-231 (a) and pancreatic cancer cell line PA-TU-8988T (b). The significance is indicated as ${ }^{*} p<0.05$. (Reproduced with permission from D. Yan et al., Sci. Rep., 2017, 7, 4479)

levels of $\mathrm{H}_{2} \mathrm{O}_{2}$ during 1 min of CAP treatment when the discharge voltage was adequately large. ${ }^{104}$ The cell-based $\mathrm{H}_{2} \mathrm{O}_{2}$ generation was also the first evidence that cancer cells could generate micromolar level toxic chemicals in their environments as an instant response to a CAP treatment. When the volume of medium was adequately small, the cell-based $\mathrm{H}_{2} \mathrm{O}_{2}$ generation could reach about $60 \mu \mathrm{M}$. It is important to note that the cell-based $\mathrm{H}_{2} \mathrm{O}_{2}$ generation would not be observed when the CAP-treated medium or $\mathrm{H}_{2} \mathrm{O}_{2}$ containing medium was used to affect the same cell lines. ${ }^{103}$ We demonstrated the presence of the cell-based $\mathrm{H}_{2} \mathrm{O}_{2}$ response in another 6 cancer cell lines (human lung carcinoma A549, human breast cancer MCF7, human colorectal carcinoma HCT116, human cervical adenocarcinoma HeLa, human bone osteosarcoma U-2 OS, murine melanoma B16F10). ${ }^{104}$

The short-lived reactive species in CAP may trigger the cellbased $\mathrm{H}_{2} \mathrm{O}_{2}$ generation. The superoxide $\left(\mathrm{O}_{2}{ }^{-}\right)$in CAP might trigger a dismutation reaction catalyzed by the extracellular superoxide dismutase (Ex-SOD) such as SOD3 on the cytoplasmic membrane of cancer cells. ${ }^{103,105,106}$ SOD3 is expressed in human tumorous tissues, such as the estrogen-induced breast cancerous tissues and pancreatic adenocarcinoma tissues. ${ }^{107-109}$ Such specific expression (a)

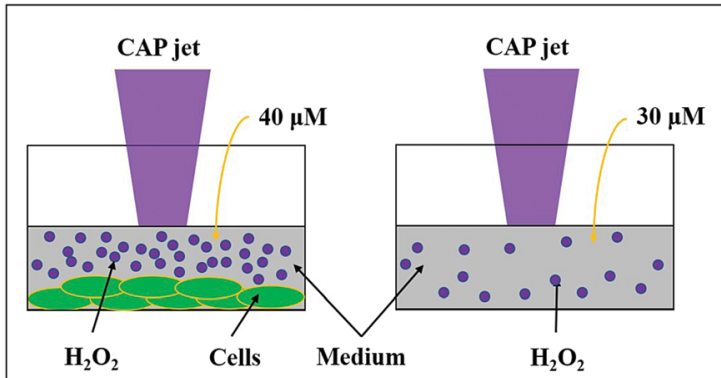

Instant measurement, $<30 \mathrm{~s}$ after treatment.

Cell-based $\mathrm{H}_{2} \mathrm{O}_{2}$ generation $=40 \mu \mathrm{M}-30 \mu \mathrm{M}=10 \mu \mathrm{M}$

(b)

$\begin{array}{ll}\square \text { DMEM } & \text { DMEM + MDA-MB-231 } \\ \square \text { DMEM + PA-TU-8988T } & \text { DMEM + U87MG }\end{array}$



Fig. 6 The cell-based $\mathrm{H}_{2} \mathrm{O}_{2}$ generation. (a) The strategy to measure the cell-based $\mathrm{H}_{2} \mathrm{O}_{2}$ generation during the CAP treatment. The measurement must be done immediately $(<30 \mathrm{~s})$ after the treatment (Reproduced with permission from D. Yan et al., Plasma Med., 2018, 8, 335-343). (b) The $\mathrm{H}_{2} \mathrm{O}_{2}$ concentration in DMEM after the CAP treatment on just DMEM (control), on pancreatic adenocarcinoma cells (PA-TU-8988T) immersed in DMEM, on breast adenocarcinoma cells (MDA-MB-231) immersed in DMEM, as well as on glioblastoma cells (U87MG) immersed in DMEM. (Reproduced with permission from D. Yan et al., Sci. Rep., 2017, 7, 10831).

of SOD3 may cause $\mathrm{H}_{2} \mathrm{O}_{2}$ generation in some cell lines such as breast cancer cell line MDA-MB-231 and pancreatic adenocarcinoma cell line PA-TU-8988T, but not all cell lines such as glioblastoma cell line U87MG shown in Fig. 6b. ${ }^{103,110}$ This suggestion is supported by the measurement of short-lived reactive species in CAP versus the increase of discharge voltage. In CAP, $\mathrm{O}_{2}{ }^{-}$can be formed by the combination of two electrons with the singlet oxygen $(\mathrm{O})$. The singlet oxygen density in CAP was calculated based on the measurement of the optical emission spectrum of CAP under different discharge conditions. ${ }^{104}$ The maximum density of $\mathrm{O}$ at the middle discharge voltage conditions has been observed in data based on OES. ${ }^{104}$

The cells-based $\mathrm{H}_{2} \mathrm{O}_{2}$ generation also provides a new clue to understanding the in vivo immune response of the CAP-treated mice. The short-lived reactive species such as superoxide or single oxygen may activate cancer cells or tissues to generate $\mathrm{H}_{2} \mathrm{O}_{2}$. The cells in the tumorous tissues may have similar interactions by generating $\mathrm{H}_{2} \mathrm{O}_{2}$ to their neighbor cells, which can explain the 
observed subcutaneous ROS in the CAP-treated mice. ${ }^{111} \mathrm{H}_{2} \mathrm{O}_{2}$ plays an important role of being a second messenger in lymphocyte activation. ${ }^{112,113}$ Micromolar levels of $\mathrm{H}_{2} \mathrm{O}_{2}$ rapidly induces the activation of an important transcription factor $\mathrm{NF}-\kappa \mathrm{B}$, the early gene expression of interleukin-2 (IL-2), as well as the IL-2 receptor. ${ }^{112}$ If the tumor generates $\mathrm{H}_{2} \mathrm{O}_{2}$ during the CAP treatment, it may become a target for the immune system. ${ }^{103,114}$ The $\mathrm{H}_{2} \mathrm{O}_{2}$-activated immune attack on tumor tissue may contribute to the anti-tumor effect of CAP treatment in vivo.

\section{The activation phenomenon}

Another difference distinguishing the direct and indirect treatment is the activation phenomenon. The CAP-treated cancer cells can quickly enter an activation state (Fig. 7a). When cancer cells enter this unique activation state, they become sensitive to the cytotoxicity of the CAP-generated reactive species, particularly the long-lived reactive species $\mathrm{H}_{2} \mathrm{O}_{2}$ and $\mathrm{NO}_{2}{ }^{-}$. The experimental demonstration of the activation state is shown in Fig. 7b. For all the cases without the activation (yellow bar), $15 \mu \mathrm{M}$ or $22 \mu \mathrm{M} \mathrm{H} \mathrm{H}_{2} \mathrm{O}_{2}$ does not cause growth inhibition on pancreatic adenocarcinoma cells PA-TU-8988T. For all the cases with the activation, there is also no cytotoxicity without the presence of extracellular $\mathrm{H}_{2} \mathrm{O}_{2}$ (orange bars). Strong growth inhibition will occur when $\mathrm{H}_{2} \mathrm{O}_{2}$ is added to affect the previously activated cells (gray bars). For example, after a 1 min of CAP treatment, there was a $30 \%$ decrease in cell viability after the addition of $15 \mu \mathrm{M} \mathrm{H}_{2} \mathrm{O}_{2}$ and a $50 \%$ decrease in cell viability after the addition of $22 \mu \mathrm{M} \mathrm{H}_{2} \mathrm{O}_{2}$. We also tested the cytotoxicity

(a)

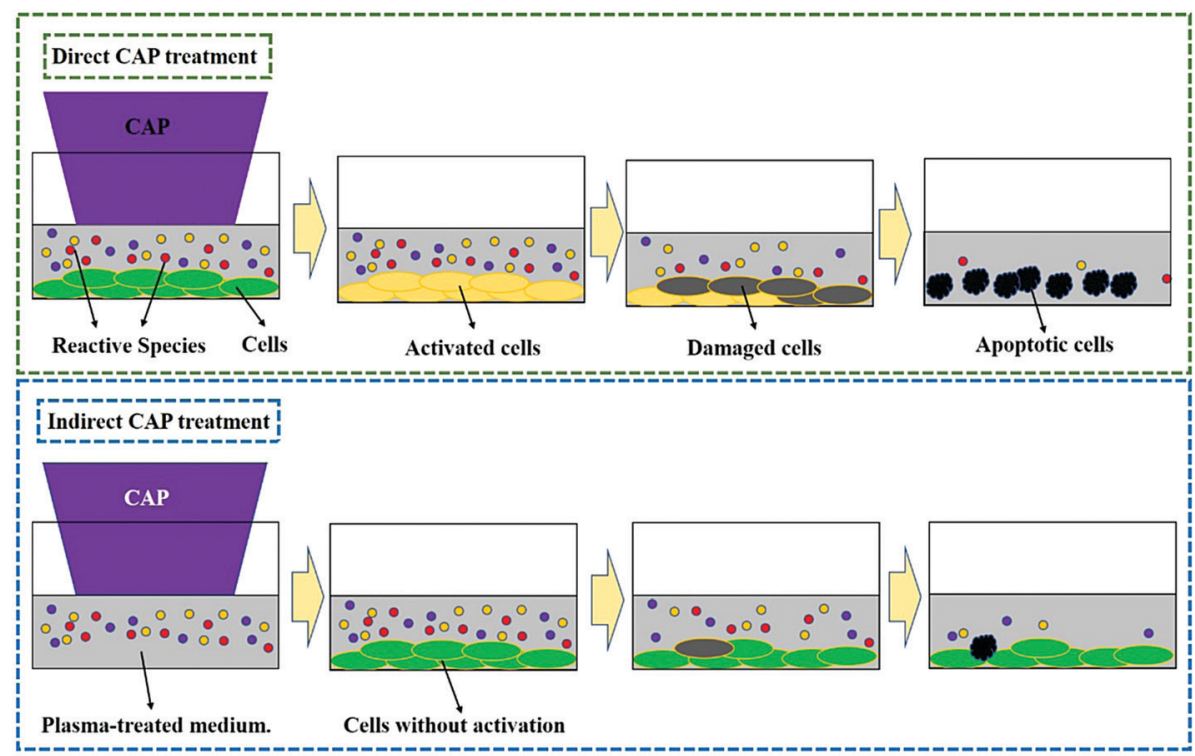

(b)

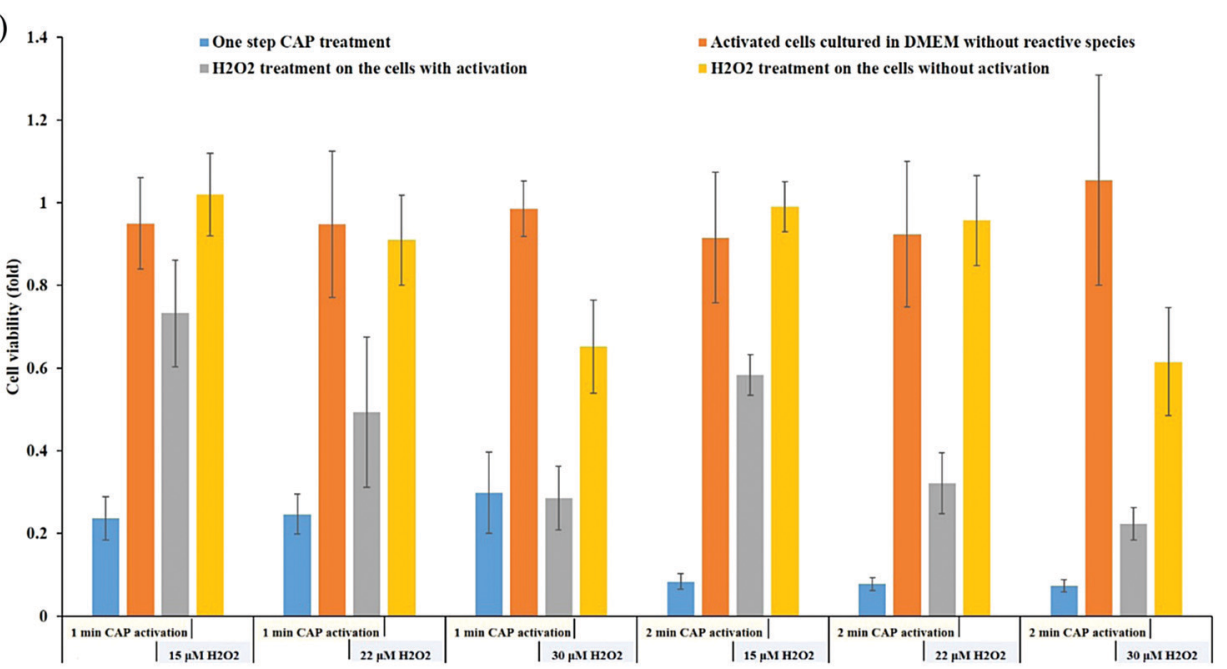

Fig. 7 The activation phenomenon of cancer cells. (a) Schematic illustration. The concentration of the CAP-originated reactive species is assumed to be the same in the two cases. The direct CAP treatment forces the cancer cells into an activation state where they are more sensitive to reactive species. (b) The "1 or 2 min CAP activation" refers to direct CAP treatment being performed on the cancer cells for 1 min or 2 min. The "15, 22, or $30 \mu \mathrm{M} \mathrm{H} \mathrm{O}_{2}$ " refers to DMEM with that specific concentration of $\mathrm{H}_{2} \mathrm{O}_{2}$ which was used to affect the growth of cancer cells with or without activation (Reproduced with permission from D. Yan et al., Sci. Rep., 2018, 8, 15418). 
of the CAP-treated medium on the same cells with and without the activation. The CAP-treated medium contains nearly all of the long-lived reactive species produced in a direct CAP treatment. A much higher percentage of cell death was achieved when the plasma-activated medium (PAM) was applied to the activated cancer cells compared to the non-activated cells. ${ }^{95}$ Finally, the activated cells also showed sensitivity to an RNS, $\mathrm{NO}_{2}{ }^{-}$. The non-activated PA-TU-8988T cells were not affected by $\mathrm{NO}_{2}{ }^{-}$even at concentrations as high as $900 \mu \mathrm{M}$. In contrast, the cell viabilty of the activated PA-TU-8988T cells drastically decreased following the addition of just $50 \mu \mathrm{M} \mathrm{NO}_{2}{ }^{-} \cdot{ }^{95}$

The CAP-induced cell activation has two basic features: a quick sensitization and a slow desensitization. ${ }^{95}$ After just 2 seconds of CAP treatment, activation was noted, however, cell activation became more prominent after 20 seconds of treatment. Unlike sensitization, the desensitization of the activated cells was a slow process. It took about 5 hours for the activated cancer cells to completely desensitize. Slow desensitization is important because the CAP-generated ROS only remains in the extracellular environment for about 3 hours after CAP treatment. The slow desensitization naturally guarantees the maximum cytotoxicity of the reactive species on the CAP-treated cancer cells.

The basic operating parameters of CAP source can be manipulated to obtain different levels of cellular activation following direct CAP treatment. ${ }^{115}$ Parameters such as the flow rate of the carrying gas (Helium), the discharge voltage, and the discharge frequency each had an impact on the activation of pancreatic cancer cells. It was found that the greatest impact on cell activation was seen with alteration of the discharge voltage. An intermediate discharge voltage had the most significant impact. A 0D chemical simulation revealed that under a particular discharge voltage, the maximum activation level could be attained when the maximum densities of short-lived reactive species produced by the CAP jet were reached. This conclusion suggests that the short-lived reactive species may contribute to the activation. However, one recent study demonstrated that the activation of the cancer cells could be realized by the extra nano pulsed magnetic field. ${ }^{116}$ Thus, it is still possible that the physical factors contribute to the activation phenomenon.

Here, we just discuss two possible activation mechanisms based on the short-lived reactive species and physical factors in CAP, respectively. In terms of the short-lived reactive species, we suggest that certain short-lived reactive species such as ${ }^{1} \mathrm{O}_{2}$ may damage the function of the membrane-bound catalases, which has been proposed to be important in the anti-cancer mechanism of CAP treatment. ${ }^{54,117}$ The damage to the extracellular catalases may not cause the death of cancer cells but may weaken the resistance of the cancer cells to the cytotoxicity of long-lived ROS. Alternatively, the physical factors in CAP may potentially trigger the activation state of cancer cells. We suggest that the electromagnetic effect in CAP may trigger the activation through the effect on ROS channels such as aquaporins (AQPs). AQPs have been screened as the main channels for transmembrane diffusion of $\mathrm{H}_{2} \mathrm{O}_{2} \cdot{ }^{118-122}$ The level of AQPs in brain cancer cells can affect the anti-cancer capacity of CAP treatment with regard to the effect of the long-lived reactive species. ${ }^{123}$
The permeability of aquaporin channels can be influenced by changes in important amino acids such as histidine and arginine, which may be affected by the extra electric fields based on the atomic dynamic simulation results. ${ }^{124-129}$ Therefore, the electromagnetic effect of CAP may increase the permeability of the reactive species channels and promote the influx of reactive species into the activated cancer cells resulting in a greater cell death rate.

\section{Summary}

We noted that a key question about the CAP cancer treatment has not been fully or properly answered. How can CAP be used as a tool in clinical cancer treatment rather than just be used in the lab? The direct CAP treatment and the indirect CAP treatment represent two quite different possible utilities of CAP cancer treatment. The former represents a surgery replacement or an assistant method to surgery, while the latter represents a potentially new pharmacological modality.

The biological effect of CAP on cancer cells has been studied for more than a decade. What we learned so far is largely limited to the long-lived reactive species-caused effect, which results in a very limited understanding of the uniqueness of CAP (Fig. 8). The discovery of the cell-based $\mathrm{H}_{2} \mathrm{O}_{2}$ generation and the activation phenomenon of CAP-treated cancer cells changes the some basic understanding of the anti-cancer mechanism. In our opinion, CAP treatment is essentially different from the conventional reactive species treatment based on long-lived reactive species such as $\mathrm{H}_{2} \mathrm{O}_{2}$. The uniqueness of CAP cancer treatment relies on its capacity to generate short-lived reactive species and other factors such as physical factors and their corresponding biological effect. The indirect CAP treatment solely depends on the actions of the long-lived reactive species, which can be easily obtained by other methods. Besides, we recently revealed that biological samples can also affect the physical properties of bulk CAP by providing feedback from the cells to the CAP

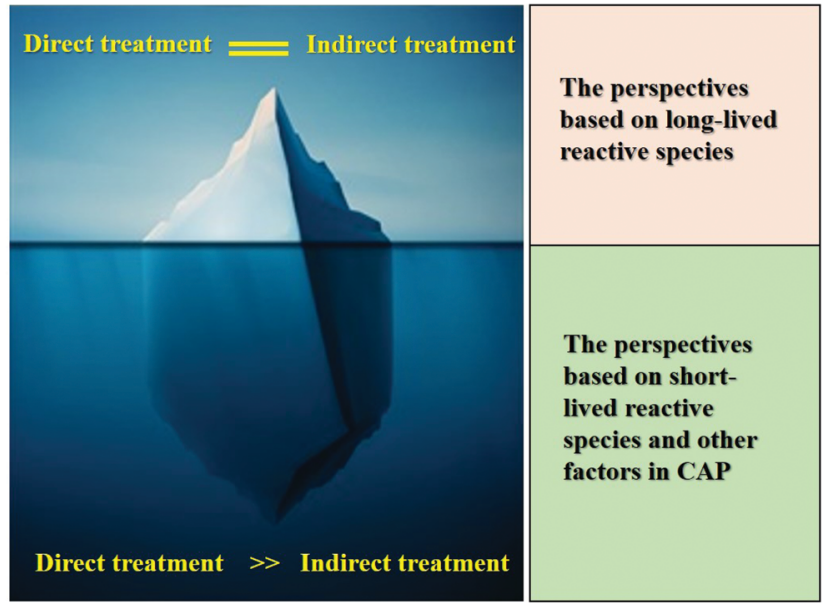

Fig. 8 The tip of the iceberg. Direct CAP treatment or the direct impact of bulk CAP on cells involves more CAP-related basic problems and unique features. The conclusions obtained from the indirect CAP treatment simplify the whole picture of the interaction between CAP and cells. 
source when the CAP jet contacts different cell lines. ${ }^{130}$ It is promising that we may see that many new unknows about the biological impact of bulk CAP, such as potential physical effect. ${ }^{131,132}$

\section{Conclusion}

In this review, the cancer treatment based on cold plasma technology has been introduced based on direct CAP treatment and indirect CAP treatment. Two new cellular responses, the cell-based $\mathrm{H}_{2} \mathrm{O}_{2}$ generation, and the activation phenomenon were illustrated as unique features to discriminate the direct from the indirect treatment. Compared with the indirect CAP treatment, which mainly relies on long-lived reactive species, the direct CAP treatment involves not only the complex interaction between the short-lived reactive species with the cells but may also involve the potential physical effect on cancer cells. The short-lived reactive species may not only trigger the cellbased $\mathrm{H}_{2} \mathrm{O}_{2}$ generation but also contribute to the activation phenomenon. The physical factors may also be partially responsible for the activation phenomenon. These discoveries suggest that there are still many unknowns to explore in the direct CAPbased biological effect on the cancer cells, and these unknowns may be the keys to understanding the full uniqueness of CAP cancer treatment. Further studies on these questions may finally guide the use of CAP as a clinic cancer therapy modality.

\section{Conflicts of interest}

There are no conflicts to declare.

\section{Acknowledgements}

This work was supported by National Science Foundation grant 1747760 .

\section{References}

1 A. Bogaerts, E. Neyts, R. Gijbels and J. Van Der Mullen, Spectrochim. Acta, Part B, 2002, 57, 609-658.

2 H. Conrads and M. Schmidt, Plasma Sources Sci. Technol., 2000, 9, 441-454.

3 J. Ehlbeck, U. Schnabel, M. Polak, J. Winter, T. Von Woedtke, R. Brandenburg, D. Hagen, K. D. Weltmann, J. Ehlbeck, U. Schnabel, M. Polak, J. Winter, T. Von Woedtke, T. Von Woedtke, R. Brandenburg, T. Von Dem Hagen and K. D. Weltmann, J. Phys. D: Appl. Phys., 2011, 44, 453-459.

4 G. Y. Park, S. J. Park, M. Y. Choi, I. G. Koo, J. H. Byun, J. W. Hong, J. Y. Sim, G. J. Collins and J. K. Lee, Plasma Sources Sci. Technol., 2012, 21, 043001.

5 A. Schütze, J. Y. Jeong, S. E. Babayan, J. Park, G. S. Selwyn and R. Hicks, IEEE Trans. Plasma Sci., 1998, 26, 1685-1694.

6 C. Tendero, C. Tixier, P. Tristant, J. Desmaison and P. Leprince, Spectrochim. Acta, Part B, 2006, 61, 2-30.

7 G. Fridman, G. Friedman, A. Gutsol, A. B. Shekhter, V. N. Vasilets and A. Fridman, Plasma Processes Polym., 2008, 5, 503-533.
8 T. Von Woedtke, A. Schmidt, S. Bekeschus, K. Wende and K. D. Weltmann, In Vivo, 2019, 33, 1011-1026.

9 D. Yan, J. H. Sherman and M. Keidar, Oncotarget, 2017, 8, 15977-15995.

10 M. Keidar, Phys. Plasmas, 2018, 25, 083504.

11 J. Schlegel, J. Köritzer and V. Boxhammer, Clin. Plasma Med., 2013, 1, 2-7.

12 M. Keidar, Plasma Sources Sci. Technol., 2015, 24, 033001.

13 T. von Woedtke, S. Reuter, K. Masur and K. D. Weltmann, Phys. Rep., 2013, 530, 291-320.

14 D. B. Graves, Plasma Processes Polym., 2014, 11, 1120-1127.

15 M. Keidar, A. Shashurin, O. Volotskova, M. Ann Stepp, P. Srinivasan, A. Sandler and B. Trink, Phys. Plasmas, 2013, 20, 057101.

16 M. Laroussi and T. Akan, Plasma Processes Polym., 2007, 4, 777-788.

17 G. Y. Park, S. J. Park, M. Y. Choi, I. G. Koo, J. H. Byun, J. W. Hong, J. Y. Sim, G. J. Collins and J. K. Lee, Plasma Sources Sci. Technol., 2012, 21, 043001.

18 M. Laroussi, IEEE Trans. Plasma Sci., 2015, 43, 703-712.

19 P. J. Bruggeman, M. J. Kushner, B. R. Locke, J. G. E. Gardeniers, W. G. Graham, D. B. Graves, R. C. H. M. Hofman-Caris, D. Maric, J. P. Reid, E. Ceriani, D. Fernandez Rivas, J. E. Foster, S. C. Garrick, Y. Gorbanev, S. Hamaguchi, F. Iza, H. Jablonowski, E. Klimova, J. Kolb, F. Krcma, P. Lukes, Z. Machala, I. Marinov, D. Mariotti, S. Mededovic Thagard, D. Minakata, E. C. Neyts, J. Pawlat, Z. L. Petrovic, R. Pflieger, S. Reuter, D. C. Schram, S. Schröter, M. Shiraiwa, B. Tarabová, P. A. Tsai, J. R. R. Verlet, T. von Woedtke, K. R. Wilson, K. Yasui and G. Zvereva, Plasma Sources Sci. Technol., 2016, 25, 053002.

20 G. Fridman, A. Shereshevsky, M. M. Jost, A. D. Brooks, A. Fridman, A. Gutsol, V. Vasilets and G. Friedman, Plasma Chem. Plasma Process., 2007, 27, 163-176.

21 M. Vandamme, E. Robert, S. Dozias, J. Sobilo, S. Lerondel, A. Le Pape and J.-M. Pouvesle, Plasma Med., 2011, 1, 27-43.

22 M. Keidar, R. Walk, A. Shashurin, P. Srinivasan, A. Sandler, S. Dasgupta, R. Ravi, R. Guerrero-Preston and B. Trink, Br. J. Cancer, 2011, 105, 1295-1301.

23 L. Brullé, M. Vandamme, D. Riès, E. Martel, E. Robert, S. Lerondel, V. Trichet, S. Richard, J. M. Pouvesle and A. Le Pape, PLoS One, 2012, 7, e52653.

24 M. Vandamme, E. Robert, S. Lerondel, V. Sarron, D. Ries, S. Dozias, J. Sobilo, D. Gosset, C. Kieda, B. Legrain, J. M. Pouvesle and A. Le Pape, Int. J. Cancer, 2012, 130, 2185-2194.

25 R. M. Walk, J. A. Snyder, P. Srinivasan, J. Kirsch, S. O. Diaz, F. C. Blanco, A. Shashurin, M. Keidar and A. D. Sandler, J. Pediatr. Surg., 2013, 48, 67-73.

26 S. U. Kang, J.-H. Cho, J. W. Chang, Y. S. Shin, K. I. Kim, J. K. Park, S. S. Yang, J.-S. Lee, E. Moon, K. Lee and C.-H. Kim, Cell Death Dis., 2014, 5, e1056.

27 N. Chernets, D. S. Kurpad, V. Alexeev, D. B. Rodrigues and T. A. Freeman, Plasma Processes Polym., 2015, 12, 1400-1409.

28 S. Mirpour, S. Piroozmand, N. Soleimani, N. Jalali Faharani, H. Ghomi, H. Fotovat Eskandari, A. M. Sharifi, S. Mirpour, M. Eftekhari and M. Nikkhah, Sci. Rep., 2016, 6, 29048. 
29 J. I. Ikeda, Y. Tsuruta, S. Nojima, H. Sakakita, M. Hori and Y. Ikehara, Plasma Processes Polym., 2015, 12, 1370-1376.

30 N. K. Kaushik, N. Kaushik, K. C. Yoo, N. Uddin, J. S. Kim, S. J. Lee and E. H. Choi, Biomaterials, 2016, 87, 118-130.

31 Y. Binenbaum, G. Ben-David, Z. Gil, Y. Z. Slutsker, M. A. Ryzhkov, J. Felsteiner, Y. E. Krasik and J. T. Cohen, PLoS One, 2017, 12, e0169457.

32 H. R. Metelmann, C. Seebauer, V. Miller, A. Fridman, G. Bauer, D. B. Graves, J.-M. Pouvesle, R. Rutkowski, M. Schuster, S. Bekeschus, K. Wende, K. Masur, S. Hasse, T. Gerling, M. Hori, H. Tanaka, E. Ha Choi, K. D. Weltmann, P. H. Metelmann, D. D. Von Hoff and T. von Woedtke, Clin. Plasma Med., 2017, 9, 6-13.

33 M. Ishaq, Z. J. Han, S. Kumar, M. D. M. Evans and K. Ostrikov, Plasma Processes Polym., 2015, 12, 574-582.

34 J. Köritzer, V. Boxhammer, A. Schäfer, T. Shimizu, T. G. Klämpfl, Y. F. Li, C. Welz, S. Schwenk-Zieger, G. E. Morfill, J. L. Zimmermann and J. Schlegel, PLoS One, 2013, 8, e64498.

35 S. Lee, H. Lee, D. Jeong, J. Ham, S. Park, E. H. Choi and S. J. Kim, Free Radicals Biol. Med., 2017, 110, 280-290.

36 S. Park, H. Kim, H. W. Ji, H. W. Kim, S. H. Yun, E. H. Choi and S. J. Kim, Cancers, 2019, 11, 2011.

37 H. Yang, R. Lu, Y. Xian, L. Gan, X. Lu and X. Yang, Phys. Plasmas, 2015, 22, 122006.

38 S. Mirpour, H. Ghomi, S. Piroozmand and M. Nikkhah, IEEE Trans. Plasma Sci., 2014, 42, 315-322.

39 K. Torii, S. Yamada, K. Nakamura, H. Tanaka, H. Kajiyama, K. Tanahashi, N. Iwata, M. Kanda, D. Kobayashi, C. Tanaka, T. Fujii, G. Nakayama, M. Koike, H. Sugimoto, S. Nomoto, A. Natsume, M. Fujiwara, M. Mizuno, M. Hori, H. Saya and Y. Kodera, Gastric Cancer, 2015, 18, 635-643.

40 R. Guerrero-Preston, T. Ogawa, M. Uemura, G. Shumulinsky, B. L. Valle, F. Pirini, R. Ravi, D. Sidransky, M. Keidar and B. Trink, Int. J. Mol. Med., 2014, 34, 941-946.

41 S. Ja Kim, H. Min Joh and T. H. Chung, Appl. Phys. Lett., 2013, 103, 153705.

42 S. Iseki, K. Nakamura, M. Hayashi, H. Tanaka, H. Kondo, H. Kajiyama, H. Kano, F. Kikkawa and M. Hori, Appl. Phys. Lett., 2012, 100, 113702.

43 X. Cheng, W. Murphy, N. Recek, D. Yan, U. Cvelbar, A. Vesel, M. Mozetič, J. Canady, M. Keidar and J. H. Sherman, J. Phys. D: Appl. Phys., 2014, 47, 335402.

44 W. Zhu, S. J. Lee, N. J. Castro, D. Yan, M. Keidar and L. G. Zhang, Sci. Rep., 2016, 6, 21974.

45 A. Jalili, S. Irani and R. Mirfakhraie, OncoTargets Ther., 2016, 9, 5911-5917.

46 G. C. Kim, G. J. Kim, S. R. Park, S. M. Jeon, H. J. Seo, F. Iza and J. K. Lee, J. Phys. D: Appl. Phys., 2008, 42, 032005.

47 Z. He, K. Liu, E. Manalo, A. Casey, G. P. Cribaro, H. J. Byrne, F. Tian, C. Barcia, G. E. Conway, P. J. Cullen and J. F. Curtin, Sci. Rep., 2018, 8, 5298.

48 N. K. Kaushik, N. Kaushik, R. Wahab, P. Bhartiya, N. N. Linh, F. Khan, A. A. Al-Khedhairy and E. H. Choi, Cancers, 2020, $12,457$.
49 X. Cheng, K. Rajjoub, A. Shashurin, D. Yan, J. H. Sherman, K. Bian, F. Murad and M. Keidar, Bioelectromagnetics, 2017, 38, 53-62.

50 C. M. Wol, J. F. Kolb, K. Weltmann, T. Von Woedtke and S. Bekeschus, Cancers, 2020, 12, 845.

51 X. Yan, Z. Xiong, F. Zou, S. Zhao, X. Lu, G. Yang, G. He and K. Ostrikov, Plasma Processes Polym., 2012, 9, 59-66.

52 H. J. Ahn, K. Il Kim, N. N. Hoan, C. H. Kim, E. Moon, K. S. Choi, S. S. Yang and J. S. Lee, PLoS One, 2014, 9, e86173.

53 H. J. Ahn, K. Il Kim, G. Kim, E. Moon, S. S. Yang and J. S. Lee, PLoS One, 2011, 6, e28154.

54 G. Bauer and D. B. Graves, Plasma Processes Polym., 2016, 13, 1157-1178.

55 M. Thiyagarajan, H. Anderson and X. F. Gonzales, Biotechnol. Bioeng., 2014, 111, 565-574.

56 S. Arndt, E. Wacker, Y. F. Li, T. Shimizu, H. M. Thomas, G. E. Morfill, S. Karrer, J. L. Zimmermann and A. K. Bosserhoff, Exp. Dermatol., 2013, 22, 284-289.

57 N. Kaushik, N. Uddin, G. B. Sim, Y. J. Hong, K. Y. Baik, C. H. Kim, S. J. Lee and N. K. Kaushik, Sci. Rep., 2015, $5,8587$.

58 M. Ishaq, K. Bazaka and K. Ostrikov, J. Phys. D: Appl. Phys., 2015, 48, 464002.

59 G. J. Kim, W. Kim, K. T. Kim and J. K. Lee, Appl. Phys. Lett., 2010, 96, 021502.

60 L. Shi, F. Ito, Y. Wang, Y. Okazaki, H. Tanaka, M. Mizuno, M. Hori, T. Hirayama, H. Nagasawa, D. R. Richardson and S. Toyokuni, Free Radicals Biol. Med., 2017, 108, 904-917.

61 M. Adhikari, B. Adhikari and B. Ghimire, Int. J. Mol. Sci., 2020, 21, 1939.

62 D. Yan, A. Talbot, N. Nourmohammadi, X. Cheng, J. Canady, J. Sherman and M. Keidar, Sci. Rep., 2015, 5, 18339.

63 G. Jian, K. Huang and J. Wang, Food Control, 2015, 50, 482-490.

64 T. Ito, G. Uchida, A. Nakajima, K. Takenaka and Y. Setsuhara, Jpn. J. Appl. Phys., 2016, 56, 01AC06.

65 B. R. Locke and K. Y. Shih, Plasma Sources Sci. Technol., 2011, 20, 034006.

66 K. D. Weltmann and T. Von Woedtke, Plasma Phys. Controlled Fusion, 2016, 59, 014031.

67 D. Yan, J. H. Sherman and M. Keidar, Cold Plasma Cancer Therapy, Morgan \& Claypool Publishers, San Rafael, 2019.

68 M. Keidar, D. Yan, I. I. Beilis, B. Trink and J. H. Sherman, Trends Biotechnol., 2018, 36, 586-593.

69 S. Bekeschus, J. Kolata, C. Winterbourn, A. Kramer, R. Turner, K. D. Weltmann, B. Br and K. Masur, Free Radical Res., 2014, 48, 542-549.

70 S. Zhao, Z. Xiong, X. Mao, D. Meng, Q. Lei, Y. Li, P. Deng, M. Chen, M. Tu, X. Lu, G. Yang and G. He, PLoS One, 2013, 8, e73665.

71 M. Yokoyama, K. Johkura and T. Sato, Biochem. Biophys. Res. Commun., 2014, 450, 1266-1271.

72 D. Yan, N. Nourmohammadi, K. Bian, F. Murad, J. H. Sherman and M. Keidar, Sci. Rep., 2016, 6, 26016.

73 T. Adachi, H. Tanaka, S. Nonomura, H. Hara, S. I. Kondo and M. Hori, Free Radicals Biol. Med., 2015, 79, 28-44. 
74 N. Kaushik, N. Kumar, C. H. Kim, N. K. Kaushik and E. H. Choi, Plasma Processes Polym., 2014, 11, 1175-1187.

75 D. Yan, H. Cui, W. Zhu, N. Nourmohammadi, J. Milberg, L. G. Zhang, J. H. Sherman and M. Keidar, Sci. Rep., 2017, 7, 4479.

76 H. Tanaka, K. Nakamura, M. Mizuno, K. Ishikawa and K. Takeda, Sci. Rep., 2016, 6, 36282.

77 N. Kurake, H. Tanaka, K. Ishikawa, T. Kondo, M. Sekine, K. Nakamura, H. Kajiyama, F. Kikkawa, M. Mizuno and M. Hori, Arch. Biochem. Biophys., 2016, 605, 102-108.

78 P. M. Girard, A. Arbabian, M. Fleury, G. Bauville, V. Puech, M. Dutreix and J. S. Sousa, Sci. Rep., 2016, 6, 29098.

79 D. Xu, Q. Cui, Y. Xu, Z. Liu, Z. Chen, W. Xia and M. G. Kong, AIP Adv., 2018, 8, 105219.

80 S. Kalghatgi, C. M. Kelly, E. Cerchar, B. Torabi, O. Alekseev, A. Fridman, G. Friedman and J. Azizkhan-Clifford, PLoS One, 2011, 6, e16270.

81 F. Utsumi, H. Kajiyama, K. Nakamura, H. Tanaka, M. Mizuno, K. Ishikawa, H. Kondo, H. Kano, M. Hori and F. Kikkawa, PLoS One, 2013, 8, e81576.

82 K. Nakamura, Y. Peng, F. Utsumi, H. Tanaka, M. Mizuno, S. Toyokuni, M. Hori, F. Kikkawa and H. Kajiyama, Sci. Rep., 2017, 7, 6085.

83 D. Yan, J. H. Sherman and M. Keidar, Adv. Anticancer Agents Med. Chem., 2018, 18, 769-775.

84 N. Kumar, J. H. Park, S. N. Jeon, B. S. Park, E. H. Choi and P. Attri, J. Phys. D: Appl. Phys., 2016, 49, 115401.

85 D. Yan, N. Nourmohammadi, A. Talbot, J. H. Sherman and M. Keidar, J. Phys. D: Appl. Phys., 2016, 49, 274001.

86 T. Adachi, S. Nonomura, M. Horiba, T. Hirayama, T. Kamiya, H. Nagasawa and H. Hara, Sci. Rep., 2016, 6, 20928.

87 G. Bauer, Plasma Med., 2019, 9, 57-88.

88 G. Bauer, IEEE Trans. Radiat. Plasma Med. Sci., 2017, 2, 87-98.

89 H. Tanaka and K. Ishikawa, Rev. Mod. Plasma Phys., 2017, 1.1, 3.

90 H. Tanaka, M. Mizuno, K. Ishikawa, K. Nakamura, H. Kajiyama, H. Kano, F. Kikkawa and M. Hori, Plasma Med., 2011, 1, 265-277.

91 D. Yan, J. H. Sherman, X. Cheng, E. Ratovitski, J. Canady and M. Keidar, Appl. Phys. Lett., 2014, 105, 224101.

92 T. Sato, M. Yokoyama and K. Johkura, J. Phys. D: Appl. Phys., 2011, 44, 372001.

93 D. Yan, N. Nourmohammadi, J. Milberg and J. H. Sherman, Plasma Med., 2018, 8, 121-130.

94 F. Saadati, H. Mahdikia, H. Abbaszadeh and M. Abdollahifar, Sci. Rep., 2018, 8, 7689.

95 D. Yan, W. Xu, X. Yao, L. Lin, J. H. Sherman and M. Keidar, Sci. Rep., 2018, 8, 15418.

96 X. Zhang, M. Li, R. Zhou, K. Feng and S. Yang, Appl. Phys. Lett., 2008, 93, 2006-2009.

97 H. J. Lee, C. H. Shon, Y. S. Kim, S. Kim, G. C. Kim and M. G. Kong, New J. Phys., 2009, 11, 115026.

98 C. H. Kim, J. H. Bahn, S. H. Lee, G. Y. Kim, S. I. Jun, K. Lee and S. J. Baek, J. Biotechnol., 2010, 150, 530-538.

99 A. Shashurin, M. A. Stepp, T. S. Hawley, S. Pal-Ghosh, L. Brieda, S. Bronnikov, R. A. Jurjus and M. Keidar, Plasma Processes Polym., 2010, 7, 294-300.
100 N. K. Kaushik, H. Uhm and E. Ha Choi, Appl. Phys. Lett., 2012, 100, 084102.

101 M. Laroussi, Plasma Processes Polym., 2014, 12, 1138-1141.

102 X. Lu, G. V. Naidis, M. Laroussi, S. Reuter, D. B. Graves and K. Ostrikov, Phys. Rep., 2016, 630, 1-84.

103 D. Yan, H. Cui, W. Zhu, A. Talbot, L. G. Zhang, J. H. Sherman and M. Keidar, Sci. Rep., 2017, 7, 10831.

104 D. Yan, L. Lin, W. Xu, N. Nourmohammadi and H. Jonathan, Plasma Med., 2018, 8, 335-343.

105 E. Nozik-Grayck, H. B. Suliman and C. a Piantadosi, Int. J. Biochem. Cell Biol., 2005, 37, 2466-2471.

106 R. Ameziane-El-Hassani, M. Schlumberger and C. Dupuy, Nat. Rev. Endocrinol., 2016, 12, 485-494.

107 B. R. O’Leary, M. A. Fath, A. M. Bellizzi, J. E. Hrabe, A. M. Button, B. G. Allen, A. J. Case, S. Altekruse, B. A. Wagner, G. R. Buettner, C. F. Lynch, B. Y. Hernandez, W. Cozen, R. A. Beardsley, J. Keene, M. D. Henry, F. E. Domann, D. R. Spitz and J. J. Mezhir, Clin. Cancer Res., 2015, 21, 1741-1751.

108 B. Singh and H. K. Bhat, Carcinogenesis, 2012, 33, 2601-2610. 109 M. L. T. Teoh, M. P. Fitzgerald, L. W. Oberley and F. E. Domann, Cancer Res., 2009, 69, 6355-6363.

110 E. Gjika, S. Pal-ghosh, A. Tang, M. Kirschner, G. Tadvalkar, J. Canady, M. A. Stepp and M. Keidar, ACS Appl. Mater. Interfaces, 2018, 10, 9269-9279.

111 E. J. Szili, J. S. Oh, H. Fukuhara, R. Bhatia, N. Gaur, C. K. Nguyen, S. H. Hong, S. Ito, K. Ogawa, C. Kawada and T. Shuin, Plasma Sources Sci. Technol., 2017, 27, 014001.

112 M. Los, W. Dröge, K. Stricker, P. A. Baeuerle and K. Schulze-Osthoff, Eur. J. Immunol., 1995, 25, 159-165.

113 M. Reth, Nat. Immunol., 2002, 3, 1129-1134.

114 S. K. Yoo and A. Huttenlocher, Curr. Biol., 2009, 19, R553-R555.

115 D. Yan, L. Lin, W. Xu and N. Nourmohammadi, J. Phys. D: Appl. Phys., 2019, 52, 445202.

116 W. Xu, D. Yan, J. Sun, J. Chen and X. Yao, J. Phys. D: Appl. Phys., 2020, 53, 125401.

117 G. Bauer, D. Sersenová, D. B. Graves and Z. Machala, Sci. Rep., 2019, 9, 13931.

118 M. Bertolotti, G. Farinelli, M. Galli, A. Aiuti and R. Sitia, J. Leukocyte Biol., 2016, 100, 1071-1079.

119 S. Watanabe, C. S. Moniaga, S. Nielsen and M. HaraChikuma, Biochem. Biophys. Res. Commun., 2016, 471, 191-197.

120 F. Chauvigné, M. Boj, R. N. Finn and J. Cerdà, Sci. Rep., 2015, 5, 7789.

121 J. R. Thiagarajah, J. Chang, J. A. Goettel, A. S. Verkman and W. I. Lencer, Proc. Natl. Acad. Sci. U. S. A., 2017, 114, 568-573.

122 G. P. Bienert, J. K. Schjoerring and T. P. Jahn, Biochim. Biophys. Acta, Biomembr., 2006, 1758, 994-1003.

123 D. Yan, A. Talbot, N. Nourmohammadi, J. H. Sherman, X. Cheng and M. Keidar, Biointerphases, 2015, 10, 040801.

124 N. J. English and J. A. Garate, J. Chem. Phys., 2016, 145, 085102.

125 M. Bernardi, P. Marracino, M. R. Ghaani, M. Liberti, F. Del Signore, C. J. Burnham, J. Gárate, F. Apollonio and N. J. English, J. Chem. Phys., 2018, 149, 245102.

126 J. A. Garate, N. J. English and J. M. D. MacElory, J. Chem. Phys., 2011, 134, 02B613. 
127 R. Reale, N. J. English, J. Garate, P. Marracino, M. Liberti and F. Apollonio, J. Chem. Phys., 2013, 139, 11b161_1.

128 J. E. Hall, J. A. Freites and D. J. Tobias, Chem. Rev., 2019, 119, 6015-6039.

129 P. Marracino, M. Liberti, E. Trapani, C. J. Burnham, M. Avena, J. Garate, F. Apollonio and N. J. English, Int. J. Mol. Sci., 2016, 17, 1133.
130 L. Lin, D. Yan, E. Gjika, J. H. Sherman and M. Keidar, ACS Appl. Mater. Interfaces, 2019, 11, 30621-30630.

131 D. Yan, Q. Wang, A. Malyavko, D. B. Zolotukhin, M. Adhikari and M. Keidar, Sci. Rep., 2020, 10, 11788.

132 D. Yan, Q. Wang, M. Adhikari, A. Malyavko, L. Lin, D. Zolotukhin, X. Yao, M. Kirschner, J. H. Sherman and M. Keidar, ACS Appl. Mater. Interfaces, 2020, 12, 34548-34563. 